\title{
Role of Micronutrient in Rice Cultivation and Management Strategy in Organic Agriculture-A Reappraisal
}

\author{
Shaon Kumar Das \\ ICAR Research Complex for NEH Region, Sikkim Centre, Tadong, Sikkim \\ Email: shaon.iari@gmail.com
}

Received 25 April 2014; revised 23 June 2014; accepted 9 July 2014

Copyright (C) 2014 by author and Scientific Research Publishing Inc. This work is licensed under the Creative Commons Attribution International License (CC BY). http://creativecommons.org/licenses/by/4.0/

(c) (i) Open Access

\begin{abstract}
Micronutrient refers to the relative quantity of a nutrient that is required for plant growth. It takes part in metabolic activities, enzymatic process/catalysts etc. Thus these all directly and indirectly help in plant growth and development. There are 8 essential plant nutrient elements defined as micronutrients like boron (B), zinc (Zn), manganese (Mn), iron (Fe), copper (Cu), molybdenum (Mo), chlorine ( $\mathrm{Cl}$ ) and silicon (Si). They constitute in total less than $1 \%$ of the dry weight of most plants. Organic sources like farm yard manure, compost, vermicompost etc. may contain less quantity of these nutrients but presence of these help the plant in their growth and development. They also called trace elements or minor elements. They are required only in small amounts ( 5 to $200 \mathrm{ppm}$, or less than $0.02 \%$ dry weight). The visual symptoms may be caused by more than one nutrient. Deficiency of one nutrient may be related to an excess quantity of another. Nutrient deficiency symptoms are observed only after the crop has already suffered an irretrievable loss. When soil supplies more quantity of nutrient than the plant's requirement, plant shows toxicity symptom.
\end{abstract}

\section{Keywords}

Micronutrient, Trace Element, Minor Elements, Deficiency, Plant Growth, Toxicity

\section{Introduction}

Micronutrient does not mean that they are less important to plants than other nutrients. Plant growth and development may be retarded if any of these elements is lacking in the soil or is not adequately balanced with other

${ }^{*}$ Corresponding author. 
nutrients. Inorganic micronutrients occur naturally in soil minerals. The parent material from which the soil developed and soil forming processes determines what the micronutrient content of the soil will be. As minerals break down during soil formation, micronutrients are gradually released in a form that is available to plants. Two sources of readily available micronutrients exist in soil: nutrients that are adsorbed onto soil colloids (very small soil particles) and nutrients that are in the form of salts dissolved in the soil solution [1]. Organic matter is an important secondary source of some micronutrients. Most micronutrients are held tightly in complex organic compounds and may not be readily available to plants. However, they can be an important source of micronutrients when they are slowly released into a plant available form as organic matter decomposes.

\section{Micronutrient Deficiencies in Crops}

Micronutrient deficiencies are widespread. 50\% of world cereal soils are deficient in zinc and 30\% of cultivated soils globally are deficient in iron. Steady growth of crop yields during recent decades (in particular through the green revolution) compounded the problem by progressively depleting soil micronutrient pools. In general, farmers only apply micronutrients when crops show deficiency symptoms, while micronutrient deficiencies decrease yields before symptoms appear [1]. Some common farming practices (such as liming acid soils) contribute to widespread occurrence of micronutrient deficiencies in crops by decreasing the availability of the micronutrients present in the soil. Major problems in alleviating micronutrient deficiencies include difficulty in the identification of field crop symptoms, variation in soil micronutrient status, soil $\mathrm{pH}$, and intensity, and seasonal fluctuations in the levels and temperature regimes in the region, inadequate facilities and field tests to validate soil and plant micronutrients in the region [2]. Assessment of micronutrient deficiency can be made through visual leaf symptoms and soil and plant analyses. Response of crops to the application of micronutrients not only confirms the deficiencies but also helps in determining nutrient needs.

\section{Micronutrient Disorders}

Various agronomic approaches can be used to correct micronutrient disorders. Once a deficiency is reliably identified, it can generally be corrected by chemical amendments that suit the plant demand and farmer options. The amount, form, mode and timing are critical, especially if multiple nutrient stresses and antagonisms among nutrients are present. Toxicities are more difficult to handle than nutrient deficiencies [2]. Direct toxicities occur when excess element is absorbed and retards physiological functions or becomes lethal to the plant. Indirect toxicity may occur through interactions; excess uptake of one nutrient may hamper the uptake, transport and utilization of another nutrient and may result in its deficiency.

\section{Zinc (Zn)}

It is the most common micronutrient disorders in wet-land rice (often combined with $\mathrm{P}$ deficiency). Due to increase availability of $\mathrm{Ca}, \mathrm{Mg}, \mathrm{Cu}, \mathrm{Fe}, \mathrm{Mn}$ and $\mathrm{P}$ under prolonged submergence $\mathrm{Zn}$ availability and uptake hampered by the crops. Zinc (Zn) deficiency is the most widespread micronutrient disorder in rice, but efforts to develop cultivars with improved tolerance have been hampered by insufficient understanding of genetic factors contributing to tolerance [1]. Zinc is essential for several biochemical processes such as cytochrome and nucleotide synthesis, enzyme activation, chlorophyll production, maintenance of membrane activity, increase rate of seed and stalk maturation. Zinc deficiencies mainly occur when soil $\mathrm{pH}$ is, high organic matter in soil, calcareous soils with high bicarbonate content, intensively cropped soils. Paddy soil under prolonged submerged condition cause zinc deficiency. Symptoms are common on younger or middle aged leaves [2] [3]. Deficiency symptoms causes brown to dusty brown spots on younger leaves (2 - 4 weeks after transplanting) in red soils, yellowing of leaves/midrib bleaching. Symptoms are prolonged during early growth stages due to immobilization of zinc. Symptoms of zinc deficiency sometimes resemble Fe/Mn deficiencies. Zinc deficiency in rice soil is commonly known as khaira. The main symptom of khaira in rice is usually in nursery; chlorotic/yellow patches at leaf base on both sides of the midrib; restricted root growth and usually main roots turn brown. Zinc deficiency has also been associated with high bicarbonate content, a Mg:Ca ratio in soils $>1$, the use of high level of fertilizers, intensive cropping, use of high yielding cultivars, and irrigation with alkaline water [4]. The most preventing measures for zinc deficiency is selection of Zn efficient variety that is tolerant to high level of bicarbonate as well as low zinc in soil. Beside these applications of $\mathrm{ZnSO}_{4}$ in nursery beds, drain the field, seedling root dipping in $2 \%-4 \% \mathrm{ZnO}$ suspension, mid season correction by spraying $0.5 \% \mathrm{ZnSO}_{4}$ thrice at 
weekly intervals between 3 - 6 WAT etc. But curative measure for correcting are application of $20-25 \mathrm{~kg} / \mathrm{ha}$ $\mathrm{ZnSO}_{4}$ in acid soil, $22 \mathrm{~kg} \mathrm{Zn/ha} \mathrm{initially} \mathrm{followed} \mathrm{by} 5-10 \mathrm{~kg} \mathrm{Zn}$ in the later years or $50 \%$ gypsum $+10 \mathrm{t} \mathrm{GM}+$ $22 \mathrm{~kg} Z \mathrm{Zn}$ once in 2 - 3 years in sodic soils, $1.0-1.5 \mathrm{~kg} / \mathrm{ha} \mathrm{Zn}$ as foliar spray at tillering stage and 2 times latter is very helpful for correct this deficiency. Plant Zn uptake from low Zn soils can be increased by Zn mobilizing chemical rhizosphere processes.

\section{Iron ( $\mathrm{Fe})$}

The iron content in soil varies from $1 \%$ to $20 \%$, averaging $3.2 \%$, but its normal concentration in plants is only $0.005 \%$. Iron deficiency is common in upland, high $\mathrm{pH}$ and aerobic soil and toxicity is one of the major constraints to lowland rice production. It disrupts the rice plant physiology in several respects. The critical iron toxicity concentration in plant tissue depends partly on the overall nutritional status of the plant. Iron helps in the formation of chlorophyll. A deficiency of iron causes chlorosis between the veins of leaves and the deficiency symptom show first in the young leaves of plants [5]. It does not appear to be translocated from older tissues to the tip meristem and as a result growth ceases. Iron is also a structural component of nonheame molecules like ferrodoxins (stable Fe-S proteins). Ferrodoxin is the first stable redox compound of the photosynthetic electron transport chain [2]. The main important deficiency symptoms are interveinal yellowing and chlorosis of emerging leaves, less dry matter production, reduced sugar metabolism enzymes, plants become stunted with narrow leaves. Iron deficiency causes chlorosis symptoms in rice plant due to relative immobility of iron in rive plants, interveinal chlorosis on surface of the leaf showing a fine reticulate network of green setting off chlorotic areas. The main reason for iron deficiency are low concentration of iron in upland soil, coarse textured soil, low land soil with very low organic matter content, increased rhizosphere $\mathrm{pH}$ etc. Though it is the most difficult and costly micronutrient deficiency to correct it can be controlled by application of $\mathrm{FeSO}_{4} 25 \mathrm{~kg}$ /ha in between rows, application of iron containing fertilizers or foliar spary of $\mathrm{FeSO}_{4} 1 \%-3 \%$ solution. Iron toxicity is caused by toxic effects of excessive Fe uptake due to large concentration of Fe in soil solution [4] [6]. The main important toxicity symptoms of iron are tiny brown spots on lower leaves starting from tip and spread towards the leaf, base or whole leaf coloured orange-yellow to brown. Spots combine on leaf inter-veins and leaves turn orangebrown and die. Leaves appear purple-brown if Fe toxicity is severe stunted growth, extremely limited tillering. Iron toxicity can be controlled by seed treatment with Ca peroxide at $50 \%-100 \%$ seed wt., intermittent irrigation at tillering stage and by balanced fertilization.

\section{Boron (B)}

Boron is concerned with precipitating excess cations, buffer action, regulatory effect on other nutrient elements etc., development of new cells in meristematic tissue, treanslocation of sugars, starches, phosphorus etc., essential for cell wall formation. Boron deficiency occurs under moister stress and dry condition which cause reduced plant height [5]. Plants fail to produce panicles if they are affected by B deficiency at the panicle formation stage. The tips of emerging leaves are white and rolled. Soil application of B (1 - $2 \mathrm{~kg} / \mathrm{ha})$ is superior to foliar sprays. For hidden deficienct, spary $0.2 \%$ boric acid or borax at pre flowering or flower head formation stages. Excess of boron appears to inhibit the formation of starch from sugars or results in the formation of B-carbohydrate complexes, resulting in retarded grain formation [6]. The symptoms of boron toxicity are brownish leaf tips and dark brown elliptical spots on leaves, necrotic spot at panicle initiation stage. Use of boron rich ground water, excessive application of boron and high temperature are the main cause of boron toxicity. Boron toxicity can be controlled by B tolerant variety, use of irrigation water having low boron content, deep ploughing etc. Sometimes dark green leaf and brown root also occur when B is absent in soil as well as in plant.

\section{Manganese (Mn)}

The role of manganese is regarded as being closely associated with that of iron. Manganese also supports the movement of iron in the plant. It influences auxin levels in plants and high concentrations of Mn favour the breakdown of Indole Acetic Acid (IAA), takes part in electron transport in photosystem II [2]. Manganese deficiency is very common in upland rice, degraded paddy soil high in Fe content, accumulation of H2S, acid sandy or acid sulphate soil, excessive liming in acid soil etc. manganese deficiency can be corrected by application of farmyard manure, acid forming fertilizer (do not use urea), $\mathrm{MnSO}_{4}$ or $\mathrm{MnO}$ at $2-5 \mathrm{~kg} / \mathrm{ha}$ as multiple application [6]. Chelates should be avoided as $\mathrm{Fe}$ and $\mathrm{Cu}$ displaces Mn. Manganese toxicity shows brown spots on the veins 
of the leaf blade and the leaf sheath in lower leaves. Plant growth are stunted and ultimately cause less number of tillering.

\section{Silicon (Si)}

Silicon is considered a plant nutrient "anomaly" because it is presumably not essential for plant growth and development. The beneficial effects of silicon have been attributed to correction of soil toxicities arising from high levels of available $\mathrm{Mn}, \mathrm{Fe}^{2+}$ and active aluminium. Silicon also provides greater stalk strength and resistance to lodging, increased availability of phosphorus, reduced transpiration etc. Silicon tends to maintain erectness of rice leaves, increases photosynthesis because of better light interception. The oxidizing power of rice roots and accompanying tolerance to high levels of iron and manganese were found to be very dependent on silicon nutrition. The major deficiency symptoms of Si in rice are soft droopy leaves and culms, lodging of plant, severe pest-disease attack [7]. Deficiency generally occurs due to small mineral reserves in organic soil, old paddy soils of subtropical and temperate climates. Silicon deficiency can be correct by irrigation of water rich in $\mathrm{Si}$, avoid excessive application of $\mathrm{N}$ fertilizers, recycling rice hulls or hull ash, apply granular silicate fertilizers like Ca silicate: 120 - $200 \mathrm{~kg} / \mathrm{ha}$; K silicate: 40 - $60 \mathrm{~kg} / \mathrm{ha}$ for rapid correction. Foliar spray of Si at $0.1 \%-0.2 \%$ with sodium silicate improve Si nutrition.

\section{Copper (Cu)}

Copper helps in the utilization of iron during chlorophyll synthesis. Lack of copper causes iron to accumulate in the nodes of plants. It has an unique involvement in enzyme systems of plants like oxidase enzymes, terminal oxidation by cytochrome oxidase, photosynthetic electron transport mediated by plastocyanin etc. It also acts as "electron carrier" in enzymes which bring about oxidation-reduction reactions in plants. Sandy, calcareous, lateritic soil, high in organic matter induce $\mathrm{Cu}$ deficiency in soil. The main important deficiency symptoms of copper are chlorotic leaves, bluish green leaves, new leaves don't unroll and leaf tips give needle like appearance, reduced tillering, less pollen viability. Excessive liming in acid soil sometimes causes $\mathrm{Cu}$ deficiency in soil [8]. It can be control by seeding root dipping in $1 \% \mathrm{CuSO}_{4}$ suspension, apply $\mathrm{Cu}$ at $5-10 \mathrm{~kg} / \mathrm{ha}$ once in 5 years in the form of $\mathrm{CuO}$ or $\mathrm{CuSO}_{4}$. Foliar application can be done during tillering to panicle initiation stage. Soil application can also be done with $\mathrm{CuSO}_{4}$ as broadcasting or band placement.

\section{Molybdenum (Mo)}

Molybdenum is an essential component of the major enzyme nitrate reductase in plants. Its requirement of plants is influenced by the form of inorganic nitrogen supplied to plants, with either nitrite $\left(\mathrm{NO}_{2}^{-}\right)$or ammonium $\left(\mathrm{NH}_{4}^{+}\right)$effectively lowering its need [3]. It is also reported to have an essential role in iron absorption and translocation in plants. Deficiency symptoms of Mo in rice resembles to nitrogen deficiency (older leaves become chlorotic). Necrotic spots are seen at leaf margins because of $\mathrm{NO}_{3}$ accumulation. Molybdenum deficiency can be correct by liming of acid soils to $\mathrm{pH} 6.5$ (not preferable if $\mathrm{pH}$ change is not desirable for other purposes). Beside these dusting with $\mathrm{Na} / \mathrm{NH}_{4}$ at $100-500 \mathrm{~g}$ /ha is very much beneficial. Foliar spay of $\mathrm{Na} / \mathrm{NH}_{4}$ molybdate at $0.1 \%$ is also beneficial [9].

\section{Fixation of Micronutrients in Soil}

Boron and molybdenum are generally fixed in rice soil. In case of boron main reaction occur when acid soils are limed. Lime is able to replace $\mathrm{Al}^{3+}$ by $\mathrm{Ca}^{2+}$ and produce insoluble precipitation of aluminium hydroxide/iron hydroxide. This precipitate adsorbs large quantities of boron. Soil high in organic matter also has high Boron. Molybdenum adsorbed strongly by iron/aluminium oxides. Soils high in non crystalline iron on clay surfeces, tend to be low in available molybdenum due to fixation [7]-[9].

\section{Nutrient Interaction and Plant Nutrition}

- Low levels of N, S \& Mg exhibited high Mn and low Fe uptake

- P induced Zn deficiency: High level of available P

o $\mathrm{ZnSO}_{4}$ application at 15 - $20 \mathrm{~kg} / \mathrm{ha}$

- Application of K decrease Mn \& Fe content in rice plant 
- Increase in $\mathrm{pH}$ by lime application reduce Zn availability to plants

- Application of Zn depress extractable Fe but increase Mn in submerged rice soil

- Application of $\mathrm{Cu}$ decrease Fe \& Mn in submerged rice soil

- High Fe in soil suppress $\mathrm{Cu}$ absorption by rice

- Fe plays an antagonistic role in relation to $\mathrm{Zn}$ in rice plant $\&$ waterlogged rice plant

- Mn inhibit Zn absorption by rice root, but favored Zn translocation within plants

- Mn interferes with translocation of Fe from root to shoot

- Calcareous soil + high pH: Iron chlorosis due to iron remaining in ferric (oxidized state)

o inundation for 2 - 3 days or foliar application of iron

- Iron toxicity: Acidic soil (liming is best way)

o Zinc deficiency: Normal \& saline-sodic soils- $\mathrm{ZnSO}_{4}$ application at $40 \mathrm{~kg} / \mathrm{ha}$

Table 1. Micronutrient content of different organic product (ppm) is presented in Table 1.

\begin{tabular}{ccccccc}
\hline Sources & Iron $(\mathrm{Fe})$ & Copper $(\mathrm{Cu})$ & Zinc $(\mathrm{Zn})$ & Manganese $(\mathrm{Mn})$ & Boron (B) & Molybdenum (Mo) \\
\hline FYM & 2600 & 2.5 & 57 & 250 & 2.1 & 0.13 \\
Compost & - & 450 & 9.4 & 12.4 & 5.8 & 0.10 \\
Pig manure & 1200 & 8.9 & 50 & 70 & 5.0 & - \\
Poultry manure & 1400 & 7.1 & 90 & 210 & 4600 & - \\
Goat manure & - & 61 & 2570 & 150 & & - \\
\hline
\end{tabular}

\section{Conclusion}

More information on the transformation and availability of micronutrients for different soils and the effect of manipulating the soil physical environment and its moisture regimes on plant available micronutrients need to be generated. Continuous use of farmyard manure or of other organic sources arrests the depletion of available micronutrient pools from soils. Development of integrated micronutrient technology using available organic materials is needed not only to increase micronutrient use efficiency but also to decrease the pressure on the use of costly inorganic micronutrient carriers. Field experiments have proved the superiority of zinc sulfate as a zinc carrier. Increasing costs coupled with a shortfall in supply of zinc sulfate have necessitated investigations on evaluating sparingly soluble zinc sources or ores combined with zinc mobilizers. The residual availability of various sources of micronutrients for a cropping system needs to be worked out.

\section{References}

[1] Rice Knowledge Management Portal. http://www.rkmp.co.in/

[2] International Rice Research Institute. http://www.irri.org/?gclid=CInQ2LCuj7sCFSg B4god8WoA0Q

[3] Introductory Soil Science, Dilip Kumar Das, Kanyani Publisher.

[4] Zhu, Z., Wei, G., Li, J., Qian, Q. and Yu, J. (2004) Silicon Alleviates Salt Stress and Increases Antioxidant Enzymes Activity in Leaves of Salt-Stressed Cucumber (Cucumis sativus L.). Plant Science, 167, 527-533. http://dx.doi.org/10.1016/j.plantsci.2004.04.020

[5] Zu, C., Wu, H.S., Tan, L.H., Yu, H., Yang, J.F., Li, Z.G., et al. (2012) Analysis of Correlation between Soil pH and Nutrient Concentrations across Hainan Black Pepper Advantage Region. Chinese Journal of Tropical Crops, 33, 1174-1179.

[6] Chaudhary, F.M. and Wallance, A. (1976) Zinc Uptake by Rice as Affected by Iron and a Chaletor of Ferrous Iron. Plant and Soil, 45, 697-700. http://dx.doi.org/10.1007/BF00010591

[7] Johnson, S.E., Lauren, J.G., Welch, R.M. and Duxbury, J.M. (2005) A Comparison of the Effects of Micronutrients Seed Priming and Soil Fertilization on the Mineral Nutrition of Chickpea (Cicer arietinum), Lentil (Lens culinaris), Rice (Oryza sativa) and Wheat (Triticum aestivum) in Nepal. Experimental Agriculture, 41, 427-448. http://dx.doi.org/10.1017/S0014479705002851

[8] Rafique, E., Rashid, A., Bhatti, A.U., Rasool, G. and Bughio, N. (2002) Boron Deficiency in Cotton in Calcareous Soil of Pakistan. In: Goldbach, H.E., et al., Eds., Distribution of B Availability and Comparison of Soil Testing Methods, Boron in Plant and Animal Nutrition, Kluwer Academic/Plenum Publisher, New York, 349-356.

[9] Graham, R.D. and Welch, R.M. (2002) Plant Food Micronutrient Composition and Human Nutrition. Communication of Soil Science \& Plant Analysis, 31, 1627-1640. http://dx.doi.org/10.1080/00103620009370529 
Scientific Research Publishing (SCIRP) is one of the largest Open Access journal publishers. It is currently publishing more than 200 open access, online, peer-reviewed journals covering a wide range of academic disciplines. SCIRP serves the worldwide academic communities and contributes to the progress and application of science with its publication.

Other selected journals from SCIRP are listed as below. Submit your manuscript to us via either submit@scirp.org or Online Submission Portal.
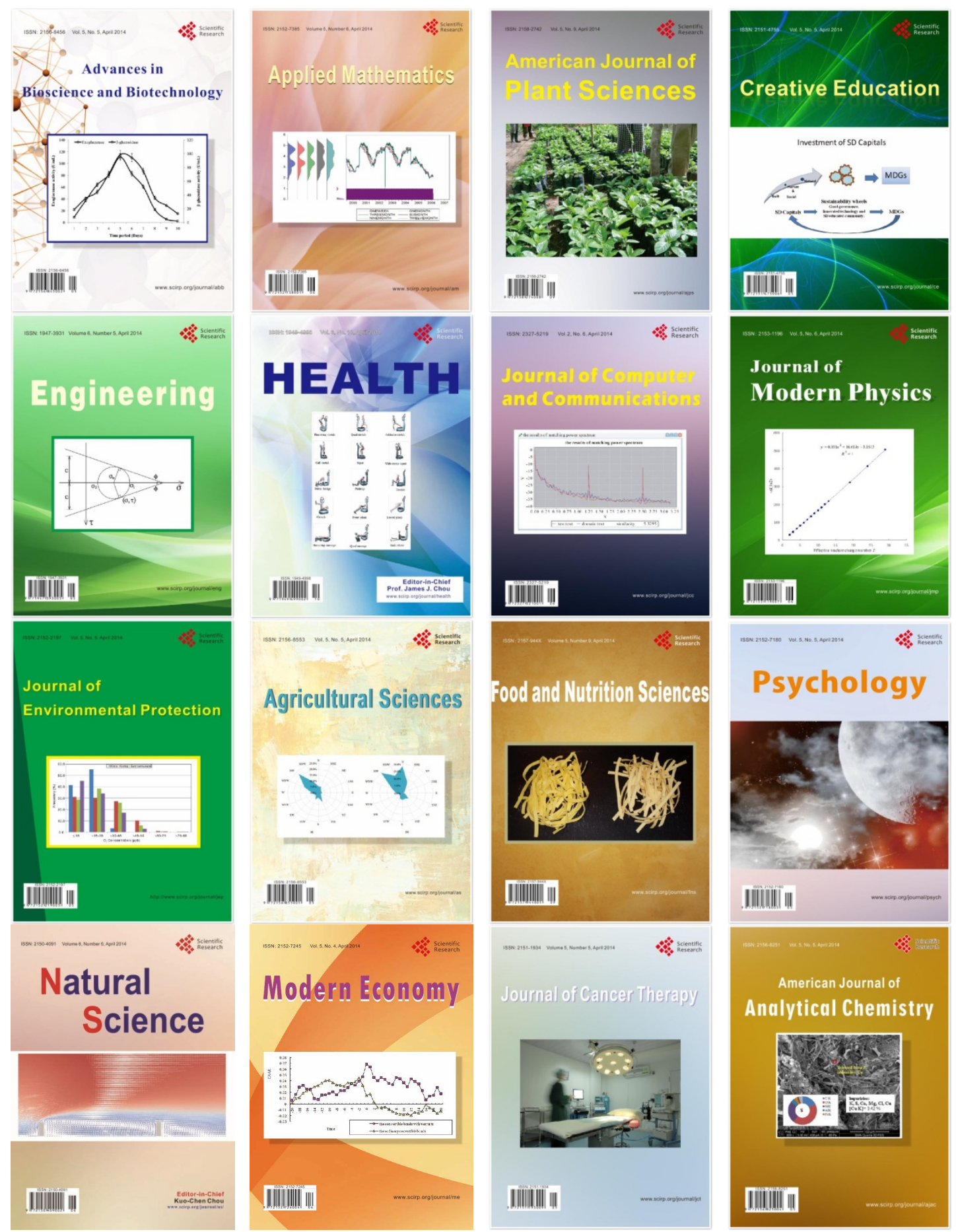